\title{
Role of novel cardiac biomarkers in prediction of cardiovascular risk in predialysis CKD patients by their correlations with left ventricular mass index
}

Satyanand Sathi ${ }^{1 *}$, Sham Sunder ${ }^{1}$, Himanshu Mahapatra', Rajesh J', Neera Sharma², Himanshu Verma', Venkataramanan K', Anurag Gupta', Prabhu K', Sunil Daksh'1, Pranith Ram¹ and Harsh Wardhan³

*Correspondence: satyanandsathi@yahoo.com

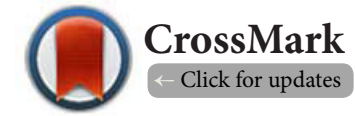

'Department of Nephrology, PGIMER \& Dr. Ram Manohar Lohia Hospital New Delhi, India. 2Department of Biochemistry, PGIMER \& Dr. Ram Manohar Lohia Hospital New Delhi, India. ${ }^{3}$ Department of cardiology, PGIMER \& Dr. Ram Manohar Lohia Hospital New Delhi, India.

\begin{abstract}
Background: Cardiac biomarkers N-terminal pro-B-type natriuretic peptide (NT-proBNP), cardiac troponin $\mathrm{T}(\mathrm{c} T \mathrm{nT})$, hsCRP and Albuminuria, predicts underlying heart disease in the general population as well as in CKD patients.

Objective: To study association of NT-proBNP, cTnT, hsCRP, spot urine albumin creatinine ratio with left ventricular mass index (LVMI) for cardiovascular risk prediction in predialysis CKD patients.

Methods: Cross section study included a total of 120 adult predialysis CKD patients. 40 patients in each predialysis CKD group of stage 3, 4 and 5 were taken. Serum cTnT, serum hsCRP, plasma NT-proBNP, single spot urine albumin creatinine ratio (UACR) were measured. Two-dimensional targeted M-mode Echocardiography was done to measure left ventricular mass index (LVMI).

Results: Mean values of Plasma NT-proBNP (pg/ml), Serum hs-CRP (mg/L), Spot UACR (mg/g of creatinine) and LVMI $\left(\mathrm{g} / \mathrm{m}^{2}\right)$ were $585.68 \pm 514.84,5.96 \pm 2.52,719.37 \pm 411.36,134.92 \pm 21.71$ respectively in predialysis CKD patients $(\mathrm{n}=120)$. Serum cTn-T level was increased in $40 \%$ of predialysis CKD patients. Among cardiovascular biomarkers plasma NT-proBNP was most strongly correlated (spearman's rho correlation coefficient; $r=0.769 \& p<0.0001)$ with the left ventricular mass index followed by spot urine albumin creatinine ratio (spearman's rho correlation coefficient; $r=0.664 \& p<0.0001$ ), serum cTn-T (spearman's rho correlation coefficient; $\mathrm{r}=0.479 \& \mathrm{p}<0.0001$ ) and serum hs-CRP (spearman's rho correlation coefficient; $r=0.246 \& p=0.007$ ).

Conclusions: Cardiovascular biomarkers plasma NT-proBNP, serum cTnT, serum hs-CRP and UACR significantly correlate with LVMI. These can predict cardiovascular risk in a predialysis CKD population with expected high cardiac morbidity and mortality.

Keywords: Novel cardiac biomarkers, spot urine albumin creatinine ratio, left ventricular mass index, predialysis CKD patients

About $40 \%$ of CKD patients have cardiovascular disease (CVD) even before they become end-stage renal disease [1]. The use of traditional risk factors such as smoking, hypertension, diabetes mellitus and dyslipidemia, results in underestimation of CVD risk in patients with CKD including predialysis patients [2]. Patients

with CKD have non-traditional or uremia related risk factors also that occur more frequently in patients of CKD and are responsible for an increased risk of CVD [3]. To identify CVD in asymptomatic predialysis CKD patients remains a big challenge in management of these patients. Recently a number of novel cardiovascular biomarkers were identified as predictor of
\end{abstract}

\section{Introduction}


patients outcome in patients with CVD [3]. Pro-BNP (108 amino acids) is a pro-hormone and it is secreted from left ventricle in response to increased myocardial wall stress [4]. On release into the circulation, proBNP is broken into two equal proportions, BNP and NT-pro-BNP. The half-life of BNP is 20 min, whereas the half-life of NT-pro-BNP is $120 \mathrm{~min}$ [5]. This is the reason that the circulating NT-pro-BNP level is approximately six-fold higher than that of BNP. Cardiac troponin-T (cTn-T) is raised in a proportion of patients with CKD and ESRD. The reasons for this remain unclear. Possible mechanisms include coronary artery disease, left ventricular dysfunction, left ventricular hypertrophy, cardiac microinfarctions and arrhythmia $[6,7]$. Non-ischemic myocardial injury due to uremic toxins, may be re-expression of fetal Troponin-T in myopathic skeletal muscles [7]. The Food and Drug Administration recently approved the use of cTnT as a biomarker for mortality risk stratification in ESRD, and the use of cTnT for prognostication is also recommended by the Kidney Disease Outcomes Quality Initiative (KDOQI) [8]. Inflamation is a very important component of pathogenesis of atherosclerosis in CKD patients. In pre- dialysis CKD patients CRP level increases as GFR decreases [9]. High-sensitivity CRP (hs-CRP) is recommended to measure cardiovascular risk caused by inflammation [10]. Albuminuria is one of the diagnostic criteria for chronic kid ney disease. Screening for albuminuria is recommended in patients at increased risk for CKD, including those with hypertension, diabetes, cardiovascular disease and a family history of CKD [11-12]. The most common manifestation of CKD is left ventricular hypertrophy (LVH), due to the high prevalence of hypertension and anemia. LVH is a powerful independent predictor of cardiovascular mortality in uremic patients. London et al., [13] found in hemodialysis patients that a $10 \%$ decrease in LV mass $(\sim 29 \mathrm{~g})$ resulted into a $28 \%$ decrease in mortality risk from cardiovascular causes during a 5-yr follow-up [13]. If correlation of cardiovascular biomarkers with LVMI is significant, then we can stratify and monitor, cardiovascular risk in CKD early, by measuring levels of biomarkers alone.

\section{Methods}

\section{Study subjects and study design}

The study was cross section study. One fifty seven indian adult patients with CKD stage 3, 4 and 5 (predialysis) were enrolled prospectively during one year period (July 2012 to June 2013). Excluded from the study were patients receiving dialysis/ESRD, patients having arteriovenous fistula, acute renal failure patients, functioning transplant patients, patients with a recent $(<1$ month) cardiac event, acute stroke patients (stroke in previous one year), patients having clinical evidence of heart failure, symptomatic coronary artery disease or arrhythmia and septicemic patients. Eleven patients did not come on the day of blood sampling. In 9 patients insufficient plasma or serum for analysis of cardiac biomarkers was obtained. Six patients had a clinical diagnosis of heart failure based on history and physical examination. Four patients showed significant ECG changes. Three patients had arteriovenous fistula. Two patient had stroke in previous one year. Two patients were found to be septicemic. Total 120 predialysis CKD patients, 40 patients in each CKD stage 3, 4 and 5 were analysed. Patients were on treatment for CKD from nephrology out patient department of our hospital. Coronary artery disease (CAD) was defined as documented old myocardial infarction, coronary artery bypass graft surgery, or percutaneous coronary intervention, and ECG with ischemic changes in apparently asymptomatic patient or presence of history of angina. The protocol and consent forms for the study were approved by the review board and ethical comity of PGIMER Dr RML Hospital, NEW DELHI, INDIA, and informed consent was obtained from each participant.

\section{Blood sampling and other analyses}

Blood samples were collected and allowed to clot for at least 30 minutes, then centrifuged at 3000 rotations per minute for 10 minutes. Samples of plasma were taken for NT-Pro-BNP measurement. Samples of serum were taken for hs-CRP and cTn-T measurement. The resulting serum and plasma were aliquoted, frozen, and maintained at $-70^{\circ} \mathrm{C}$. Samples from all patients then were thawed for quantitative measurement of biomarkers. Rest of the investigations were done on the day of sample collection. Quantitative measurement of N-terminal proBNP (NT-proBNP) was done by the Elecsys proBNP immunoassay (Roche Diagnostics, Indianapolis, IN). Cutoffs used were $125 \mathrm{pg} / \mathrm{ml}$ and $450 \mathrm{pg} / \mathrm{ml}$ for age $<75$ year and $\geq 75$ year respectively. Quantitative measurement of cardiac troponin T ( $\mathrm{CTnT}$ ) was done by the Elecsys cardiac troponin T assay (Elecsys TroponinT STAT Immunoassay, third generation; Roche Diagnostics). The limit of detection is $<0.01 \mathrm{ng} / \mathrm{mL}$, as given by the manufacturer. The $99^{\text {th }}$ percentile of a reference population is $0.01 \mathrm{ng} / \mathrm{mL}$ and the threshold for diagnosis of myocardial infarction in $0.1 \mathrm{ng} / \mathrm{mL}$. Serum hs-CRP was measured by Immunoturbidimetry method. The spot Urine albumin to creatinine ratio (UACR) measurement was done on fully automated analyzer by dry chemistry method. UACR was considered as increased when it was $\geq 30 \mathrm{mg} / \mathrm{g}$ of creatinine in a single spot urine sample. Serum creatinine was determined using the autopak reagent kit. This kit utilizes the picrate method. Estimated GFR was calculated by using the abbreviated Modification of Diet in Renal Disease study formula [14].

\section{Echocardiographic measurement}

Two-dimensionally guided M-mode echocardiography was performed. Interventricular septum thickness (IVS), posterior left ventricular wall thickness (PLVW), end-diastolic (LVEDD), and end-systolic (LVESD) left ventricular internal dimensions were measured. Left ventricular mass (LVM) was determined by the equation developed by Devereux et al., [15]. Left ventricular mass index (LVMI) was calculated by dividing LVM by body surface area. Left ventricular hypertrophy (LVH) was 
Sathi et al. Clinical Nephrology and Urology Science 2014,

considered to be present when left ventricular mass index (LVMI) exceeded $125 \mathrm{~g} /$ meter square [16,17]. Left ventricular mass $($ LVM $)=0.8 \times 1.04\left[(\text { IVS }+ \text { LVEDD }+ \text { PLVW })^{3}-\right.$ LVEDD $\left.^{3}\right]+0.6 \mathrm{~g}$.

\section{Statistical ananlyses}

Data was analysed by statistical package for social sciences (SPSS), Statistics 19 of windows-7. The data was presented as mean \pm standard deviation or frequency (\%). Pearson's correlation coefficient and spearman rank correlation coefficient were calculated for various parameters. Comparisons among three CKD stages were assessed by univariate analysis of vari-ance (ANOVA). Chi-Squared test was applied to make out the difference between the percentages of two set of values. Cutoff levels for different cardiovascular biomarkers were determined. For a particular cutoff level sensitivity, specificity of biomarkers were calculated and area under the receiver operating characteristic curve (AUROC) was plotted for biomarkers in relation to LVMI. (P) value $<0.05$ was considered as statistically significant.

\section{Results}

Clinical charecteristics for all the patients and by CKD stage are given in Table 1.

Effect of CKD stage on cardiac biomarkers concentrations There was a significant trend toward increasing plasma NTproBNP $(p<0.0001)$, serum $c \operatorname{TnT}(p=0.002)$ and spot urine albumin creatinine ratio $(p<0.0001)$ concentrations with declining

Table 1. Clinical characteristics of study patients by CKD stage.

\begin{tabular}{|c|c|c|c|c|c|}
\hline & All stages & Stage 3 & Stage 4 & Stage 5 & p-value \\
\hline Number of patients & 120 & 40 & 40 & 40 & -- \\
\hline Male/female & $70: 50$ & $27: 13$ & $25: 15$ & $18: 22$ & Ns \\
\hline Age (yrs) (mean) & $46.73 \pm 14.18$ & $44.68 \pm 15.22$ & $47.38 \pm 14.39$ & $48.05 \pm 12.96$ & Ns \\
\hline Duration of CKD(yrs) & $2.98 \pm 1.47$ & $2.25 \pm 1.19$ & $3.23 \pm 1.49$ & $3.48 \pm 1.46$ & $<0.001$ \\
\hline eGFR[mean] $\left(\mathrm{ml} / \mathrm{min} / 1.73 \mathrm{~m}^{2}\right)$ & $24.16 \pm 12.17$ & $39.21 \pm 16.48$ & $21.30 \pm 3.75$ & $11.98 \pm 1.73$ & $<0.0001$ \\
\hline Serum creatinine (mg/dl) [mean] & $3.27 \pm 1.34$ & $1.85 \pm 0.24$ & $3.12 \pm 0.54$ & $4.83 \pm 0.73$ & $<0.0001$ \\
\hline S.B.P.(mmHg) & $135.60 \pm 11.80$ & $135.38 \pm 12.24$ & $135.05 \pm 11.52$ & $136.38 \pm 11.90$ & Ns \\
\hline D.B.P.( $\mathrm{mmHg})$ & $83.16 \pm 6.87$ & $83.55 \pm 6.99$ & $82.35 \pm 7.30$ & $83.58 \pm 6.39$ & Ns \\
\hline On any anti-hypertensive (\%) & $80.83 \%$ & $72.5 \%$ & $80 \%$ & $90 \%$ & Ns \\
\hline H/O CAD (\%) & $39.16 \%$ & $32.5 \%$ & $37.5 \%$ & $47.5 \%$ & Ns \\
\hline H/O Smoking (\%) & $31 \%$ & $35 \%$ & $30 \%$ & $27.5 \%$ & Ns \\
\hline Diabetes mellitus (\%) & $40 \%$ & $37.5 \%$ & $37.5 \%$ & $45 \%$ & Ns \\
\hline $\operatorname{BSA}\left(\mathrm{m}^{2}\right)[$ mean $]$ & $1.61 \pm 0.11$ & $1.60 \pm 0.11$ & $1.62 \pm 0.12$ & $1.62 \pm 0.11$ & Ns \\
\hline $\operatorname{LVMI}\left(\mathrm{g} / \mathrm{m}^{2}\right)$ [mean] & $134.92 \pm 21.71$ & $126 \pm 14.62$ & $131.65 \pm 16.61$ & $147.10 \pm 26.54$ & $<0.0001$ \\
\hline LVH;LVMI>125g/m² (\%) & $60 \%$ & $55 \%$ & $57.5 \%$ & $67.5 \%$ & Ns \\
\hline $\operatorname{BMI}\left(\mathrm{kg} / \mathrm{m}^{2}\right)[$ mean $]$ & $22.68 \pm 2.48$ & $22.20 \pm 2.01$ & $22.99 \pm 2.85$ & $22.84 \pm 2.50$ & Ns \\
\hline Hemoglobulin (g/dl) & $10.80 \pm 1.44$ & $11.22 \pm 1.38$ & $10.83 \pm 1.34$ & $10.34 \pm 1.51$ & 0.024 \\
\hline Intact PTH (pg/ml) & $154.03 \pm 82.78$ & $87.85 \pm 25.27$ & $149.28 \pm 51.74$ & $224.98 \pm 88.97$ & $<0.0001$ \\
\hline Ca $x$ PO4 product $(\mathrm{mg} / \mathrm{dl})^{2}$ & $54.90 \pm 3.85$ & $53.20 \pm 4.12$ & $54.69 \pm 3.63$ & $54.80 \pm 3.86$ & Ns \\
\hline Serum cholesterol (mg/dl) & $167.10 \pm 43.89$ & $174.80 \pm 43.60$ & $155.90 \pm 41.50$ & $170.60 \pm 45.31$ & Ns \\
\hline Patients on statins (\%) & $48.33 \%$ & $42.5 \%$ & $50 \%$ & $52.5 \%$ & Ns \\
\hline Plasma NT-proBNP (pg/ml) & $585.68 \pm 514.84$ & $350.30 \pm 277.34$ & $613.35 \pm 561.51$ & $793.40 \pm 560.98$ & $<0.0001$ \\
\hline Serum cTnT>0.01,ng/ml (\%) & $40 \%$ & $22.5 \%$ & $37.5 \%$ & $60 \%$ & 0.002 \\
\hline Serum hs-CRP (mg/L) & $5.96 \pm 2.52$ & $5.91 \pm 2.68$ & $5.94 \pm 2.62$ & $5.99 \pm 2.31$ & Ns \\
\hline Spot UACR (mg/g of creatinine) & $719.37 \pm 411.36$ & $394.58 \pm 261.43$ & $740.43 \pm 366.39$ & $1023.10 \pm 332.39$ & $<0.0001$ \\
\hline
\end{tabular}

SBP: systolic blood pressure; DBP: diastolic blood pressure; H/O: history of; CAD: coronary artery disease; BSA: body surface area; LVMI: left ventricular mass index; LVH: left ventricular hypertrophy; BMI: body mass index; PTH: paratharmone; Ns: not significant 
estimated GFR. Median plasma NT-proBNP, median serum cTnT and median spot UACR concentrations increased across CKD stages in the order of CKD stage 3 less than stage 4 less than stage 5 (Table 1). Median serum hs-CRP concentrations did not differ significantly between patients with CKD stages 3 and 4 and 5.

Overall correlations of cardiovascular biomarkers and other variables with each other and with LVMI

For patients with all CKD stages, age, duration of CKD, systolic blood pressure, serum creatinine, serum i-PTH, serum hs-CRP plasma NT-proBNP, serum CTnT and spot UACR correlated positively and significantly with left ventricular mass index (LVMI) but hemoglobin and e GFR correlated negatively and significantly with LVMI (Table 2). Plasma NT-proBNP, serum cTnT and serum hs-CRP did not correlate significantly with age, sex, lipid profile, serum albumin, serum calcium, serum alkaline phosphatase, serum PO4, serum i-PTH and body surface area in our study.

Table 2. Overall correlations of cardiovascular biomarkers and other variables with LVMI in predialysis CKD patients $(n=120)$.

\begin{tabular}{lcl}
\hline & \multicolumn{2}{c}{ LVMI $\left(\mathbf{g} / \mathbf{m}^{2}\right)$} \\
\hline & $\begin{array}{l}\text { Correlation } \\
\text { Coefficient }(\mathbf{r})\end{array}$ & P-value \\
\hline Age (years) P & 0.197 & 0.031 \\
Duration of CKD (years) & 0.298 & 0.001 \\
e GFR mL/min/1.73 m² BSA & -0.379 & 0.0001 \\
Systolic BP $(\mathrm{mm} \mathrm{Hg})$ & 0.264 & 0.004 \\
Diastolic BP $(\mathrm{mm} \mathrm{Hg})$ & 0.112 & 0.224 \\
Hemoglobin $(\mathrm{gm} / \mathrm{dl})$ & -0.757 & 0.0001 \\
Blood urea $(\mathrm{mg} / \mathrm{dl})$ & 0.337 & 0.0001 \\
Serum creatinine $(\mathrm{mg} / \mathrm{dl})^{\mathrm{P}}$ & 0.449 & 0.0001 \\
Serum intact- PTH $(\mathrm{pg} / \mathrm{ml})^{\mathrm{P}}$ & 0.189 & 0.039 \\
Serum cTn-T $(>.01 \mathrm{ng} / \mathrm{ml})^{\mathrm{S}}$ & 0.479 & 0.0001 \\
Plasma NT-proBNP $(\mathrm{pg} / \mathrm{ml})^{\mathrm{S}}$ & 0.769 & 0.0001 \\
Serum hs-CRP $(\mathrm{mg} / \mathrm{L})^{\mathrm{S}}$ & 0.246 & 0.007 \\
UACR $(\mathrm{mg} / \mathrm{g} \text { of creatinine) })^{\mathrm{S}}$ & 0.664 & 0.0001 \\
\hline
\end{tabular}

S: spearman's rho correlation coefficient

$\mathrm{P}=$ Pearson's correlation coefficient

$(\mathrm{r})=$ Correlation coefficient

$\mathrm{UACR}=$ urine albumin creatinine ratio

CKD stage wise correlations of cardiovascular biomarkers with LVMI

Hemoglobin, plasma NT-proBNP, serum cTnT, serum hs-CRP and spot UACR correlated significantly with left ventricular mass index (LVMI) in all the three CKD stages (Table 3).

Over all correlations of cardiac biomarkers with spot urine albumin creatinine ratio

Plasma NT-proBNP, serum cTnT and serum hs-CRP correlated positively and significantly with spot urine albumin creatinine ratio but haemoglobin and eGFR correlated negatively and significantly with spot UACR (Table 4).

Table 3. CKD stage wise correlations of cardiovascular biomarkers with LVMI.

\begin{tabular}{|c|c|c|c|c|c|c|}
\hline & \multicolumn{2}{|c|}{$\begin{array}{l}\text { CKD Stage } 3 \\
(\mathrm{n}=40) \text { LVMI } \\
\left(\mathrm{g} / \mathrm{m}^{2}\right)\end{array}$} & \multicolumn{2}{|c|}{$\begin{array}{l}\text { CKD Stage } 4 \\
(n=40) \text { LVMI } \\
\left(\mathrm{g} / \mathbf{m}^{2}\right)\end{array}$} & \multicolumn{2}{|c|}{$\begin{array}{l}\text { CKD Stage } 5 \\
(\mathrm{n}=40) \\
\text { LVMI }\left(\mathrm{g} / \mathrm{m}^{2}\right)\end{array}$} \\
\hline & $(\mathbf{r})$ & (p-value) & $(\mathbf{r})$ & (p-value) & $(\mathbf{r})$ & (p-value) \\
\hline $\mathrm{Hb}(\mathrm{gm} \%)^{\mathrm{P}}$ & -0.805 & $(0.0001)$ & -0.836 & $(0.0001)$ & -0.699 & $(0.0001)$ \\
\hline $\begin{array}{l}\text { Serum cTn- } \\
\mathrm{T}(>0.01 \\
\mathrm{ng} / \mathrm{ml})\end{array}$ & 0.480 & $(0.002)^{\mathrm{P}}$ & 0.451 & $(0.003)^{\mathrm{S}}$ & 0.403 & $(0.010)^{\mathrm{s}}$ \\
\hline $\begin{array}{l}\text { Plasma NT- } \\
\text { pro- BNP } \\
(\mathrm{pg} / \mathrm{ml})^{\mathrm{s}}\end{array}$ & 0.687 & $(0.0001)$ & 0.783 & $(0.0001)$ & 0.693 & $(0.0001)$ \\
\hline $\begin{array}{l}\text { Serum } \\
\text { hs-CRP } \\
(\mathrm{mg} / \mathrm{L})^{\mathrm{s}}\end{array}$ & 0.331 & $(0.037)$ & 0.400 & $(0.010)$ & 0.401 & $(0.010)$ \\
\hline $\begin{array}{l}\text { UACR } \\
(\mathrm{mg} / \mathrm{g} \text { of } \\
\text { creatinine })^{\mathrm{s}}\end{array}$ & 0.811 & $(0.0001)$ & 0.556 & $(0.0001)$ & 0.345 & $(0.029)$ \\
\hline
\end{tabular}

$\mathrm{S}$ : spearman's rho correlation coefficient; $\mathrm{P}=$ Pearson's correlation coefficient; $(r)=$ Correlation

Table 4. Correlations of spot UACR with Hb, eGFR and other cardiovascular biomarkers.

\begin{tabular}{ll}
\hline & $\begin{array}{l}\text { UACR }(\mathbf{m g} / \mathrm{g} \text { of creatinine) } \\
\text { Correlation coefficient and } \\
\text { (p-value) }\end{array}$ \\
\hline $\mathrm{Hb}(\mathrm{gm} \%)^{\mathrm{S}}$ & $-0.507(0.0001)$ \\
$\mathrm{e} \mathrm{GFR} \mathrm{mL} / \mathrm{in} / 1.73 \mathrm{~m}^{2} \mathrm{BSA}^{\mathrm{s}}$ & $-0.641(0.0001)$ \\
Serum cTn-T $(>0.01 \mathrm{ng} / \mathrm{ml})^{\mathrm{s}}$ & $0.484(0.0001)$ \\
Plasma NT-proBNP $(\mathrm{pg} / \mathrm{ml})^{\mathrm{S}}$ & $0.610(0.0001)$ \\
Serum hs-CRP $(\mathrm{mg} / \mathrm{L})^{\mathrm{s}}$ & $0.192(0.035)$ \\
\hline
\end{tabular}

S: Spearman's rho correlation coefficient

Correlation matrix table for cardiovascular biomarkers Biomarkers were inter-related as well as they were related with LVMI as shown in Table 5.

Sensitivity, specificity and area under the receiver operating characteristic curve (AUROC) for biomarkers with respect to LVMI

For spot urine albumin creatinine ratio, at cutoff level of 629 $\mathrm{mg} / \mathrm{g}$ of creatinine ,the sensitivity, specificity and AUROC were $80.5 \%, 72.9 \%$ and 0.833 respectively in relation to LVMI (Figure 4). For serum cTnT, at cutoff level of $0.010 \mathrm{ng} / \mathrm{ml}$, the sensitivity, specificity and AUROC were $62.5 \%, 73 \%$ and 0.667 respectively in relation to LVMI (Figure 5). For plasma NT-pro BNP, at cutoff level of $300 \mathrm{pg} / \mathrm{ml}$, the sensitivity, specificity and 
Sathi et al. Clinical Nephrology and Urology Science 2014,

http://www.hoajonline.com/journals/pdf/2054-7161-1-4.pdf

doi: $10.7243 / 2054-7161-1-4$

Table 5. Correlation matrix table for cardiovascular biomarkers, showing their inter-relationship and relationship with eGFR and LVMI.

\begin{tabular}{|c|c|c|c|c|c|c|}
\hline & $\begin{array}{l}\text { eGFR }(\mathrm{mL} / \\
\left.\mathrm{min} / 1.73 \mathrm{~m}^{2}\right)\end{array}$ & $\begin{array}{l}\text { UACR (mg/g } \\
\text { of creatinine) }\end{array}$ & $\begin{array}{l}\text { cTn-T } \\
(\mathrm{ng} / \mathrm{ml})\end{array}$ & $\begin{array}{l}\text { NT-pro-BNP } \\
(\mathrm{pg} / \mathrm{ml})\end{array}$ & $\begin{array}{l}\text { hsCRP } \\
(\mathrm{mg} / \mathrm{L})\end{array}$ & $\begin{array}{l}\text { LVMI } \\
\left(\mathrm{g} / \mathrm{m}^{2}\right)\end{array}$ \\
\hline $\mathrm{eGFR}(\mathrm{mL} / \mathrm{min} / 1.73 \mathrm{~m} 2)^{\mathrm{s}}$ & -- & -- & -- & -- & -- & -- \\
\hline UACR (mg/g of creatinine $)^{\mathrm{s}}$ & -0.60 & -- & -- & -- & -- & -- \\
\hline $\mathrm{cTn}-\mathrm{T}(\mathrm{ng} / \mathrm{ml})^{\mathrm{S}}$ & -0.29 & 0.43 & -- & -- & -- & -- \\
\hline NT-pro-BNP $(\mathrm{pg} / \mathrm{ml})^{\mathrm{s}}$ & -0.31 & 0.55 & 0.43 & -- & -- & -- \\
\hline hsCRP $(\mathrm{mg} / \mathrm{L})^{\mathrm{S}}$ & -0.04 & 0.21 & 0.27 & 0.29 & -- & -- \\
\hline $\operatorname{LVMI}(\mathrm{g} / \mathrm{m} 2)^{\mathrm{s}}$ & -0.38 & 0.66 & 0.44 & 0.76 & 0.25 & -- \\
\hline
\end{tabular}

S: Spearman's rho correlation coefficient

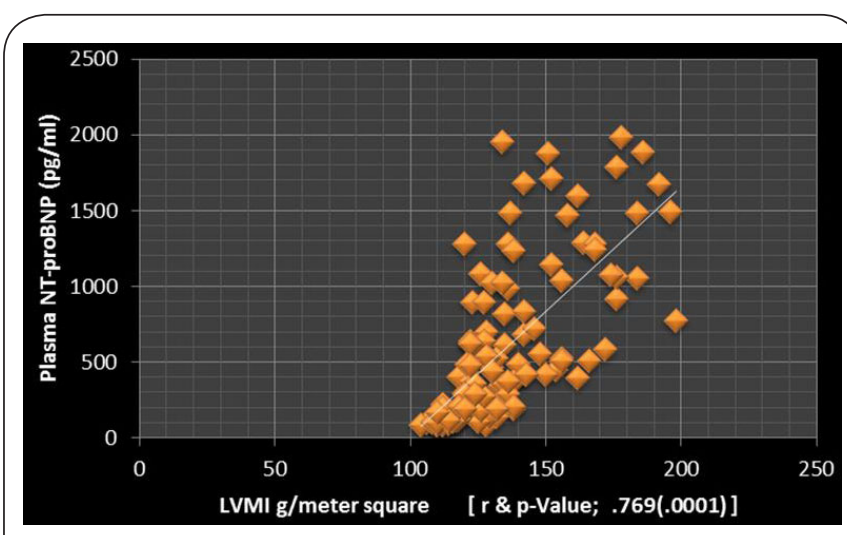

Figure 1. Correlation plot of left ventricular mass index with plasma NT-proBNP $(\mathrm{n}=120)$.

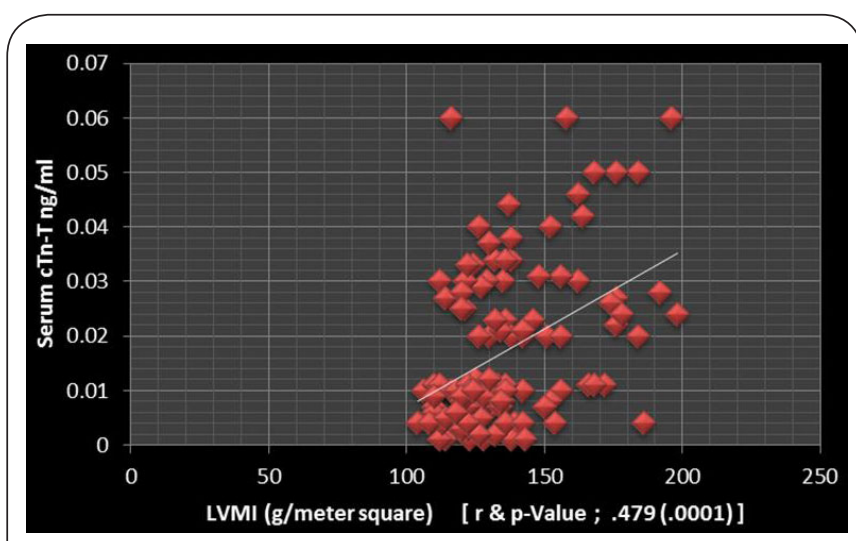

Figure 2. Correlation plot of left ventricular mass index with serum cTn-T $(n=120)$.

AUROC were $80.5 \%, 75 \%$ and 0.856 respectively in relation to LVMI (Figure 6). For serum hs-CRP, at cutoff level of $5.4 \mathrm{mg} / \mathrm{L}$, the sensitivity, specificity and AUROC were $64 \%, 50 \%$ and 0.594 respectively in relation to LVMI (Figure 7).

\section{Discussion}

Kidney disease recently has withdrawn attention as a cardiac

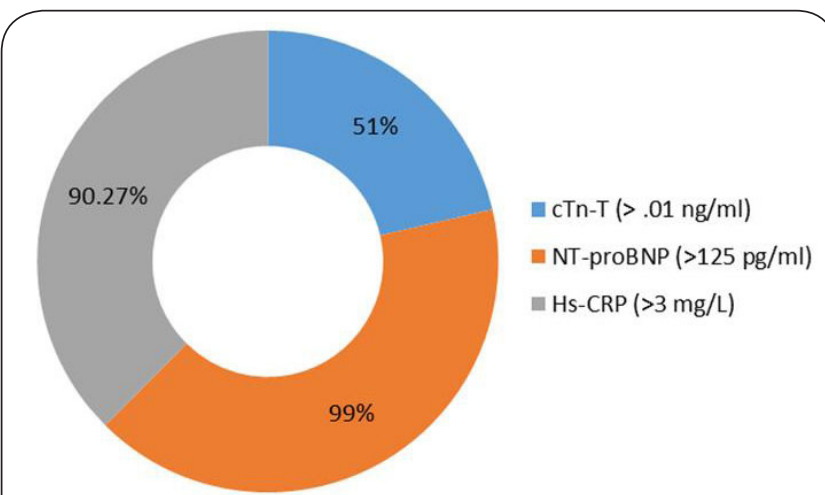

Figure 3. Prevalence of increased serum cTn-T, increased plasma NT-proBNP and increased serum hs-CRP in predialysis CKD patients having LVH $(n=72)$.

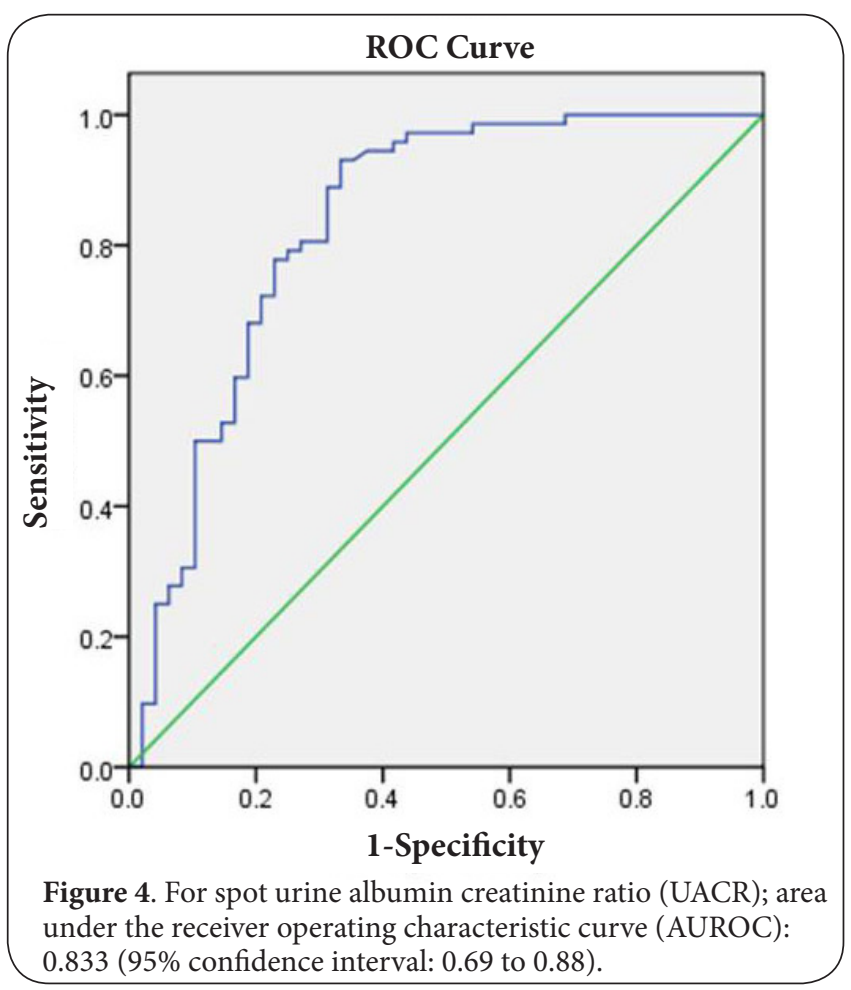




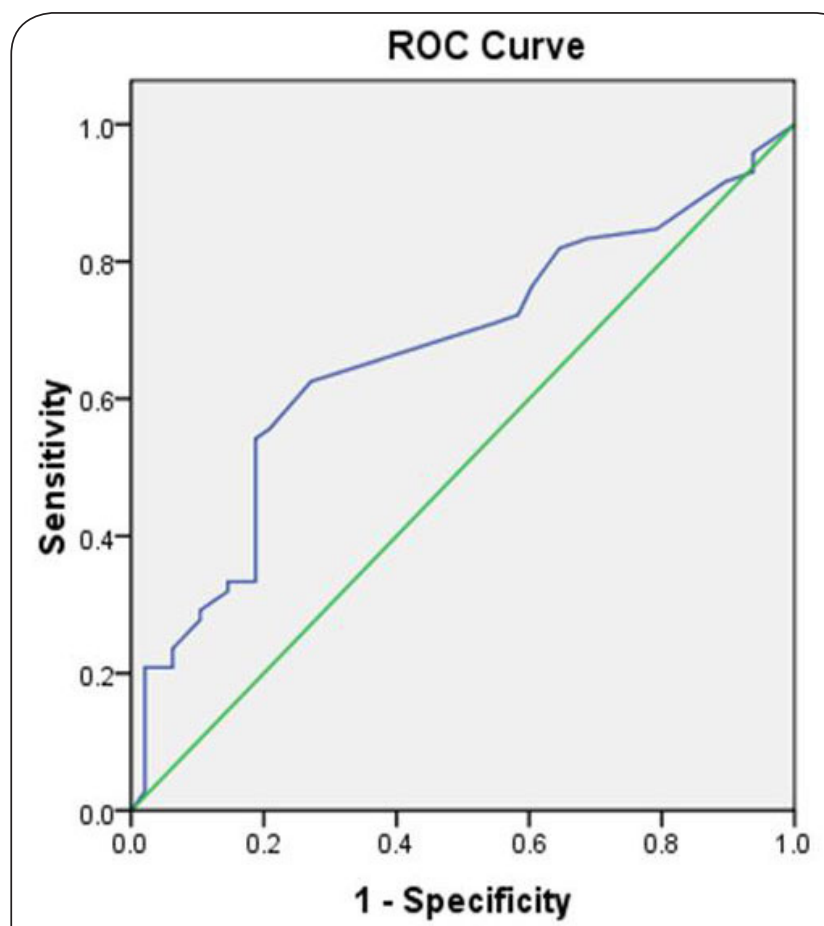

Figure 5. For serum cTnT; area under the receiver operating characteristic curve (AUROC): 0.667 (95\% confidence interval: 0.50 to 0.73 ).

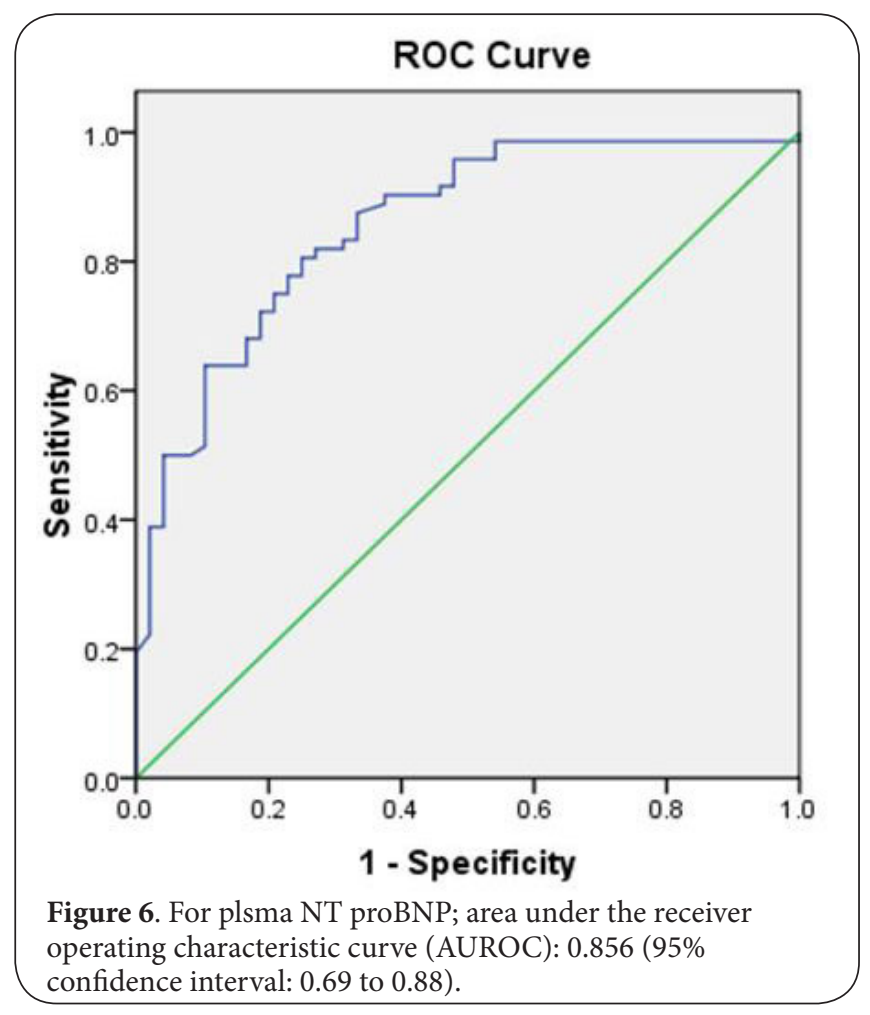

risk factor with importance similar to diabetes and history of prior cardiac disease [2]. However, stratification of cardiac risk

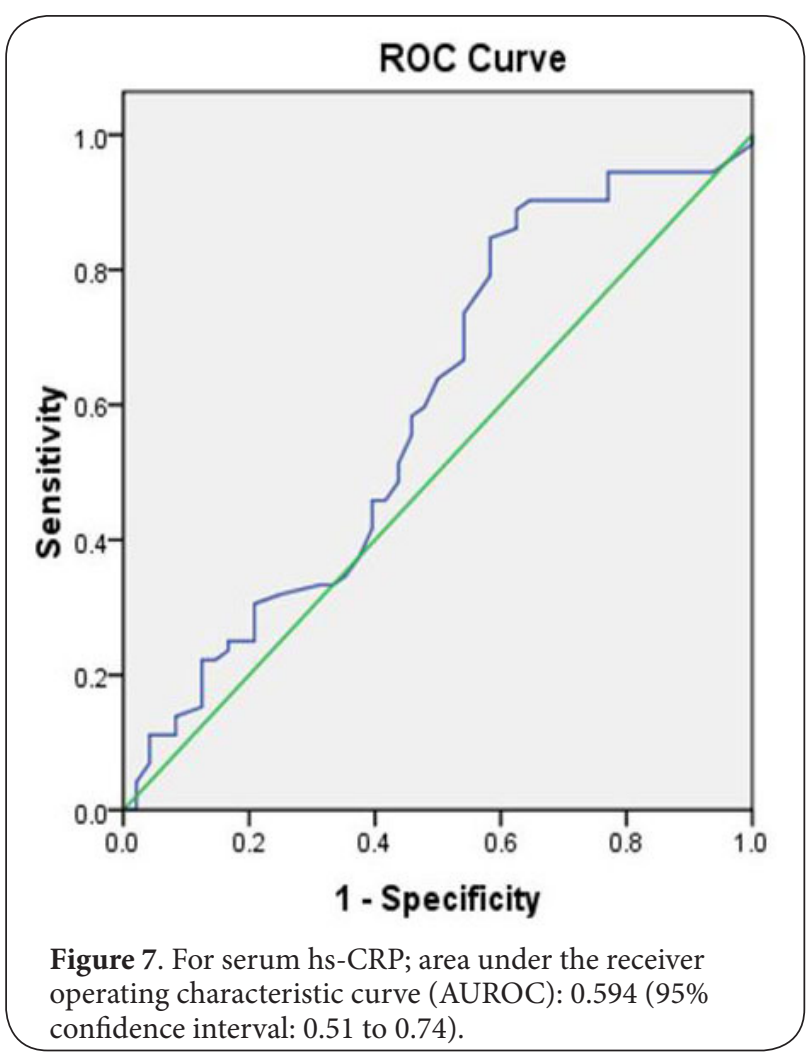

with in the asymptomatic predialysis CKD population remains challenging due to the high prevalence of traditional cardiac risk factors and left ventricular hypertrophy (LVH). If we are able to detect significant cardiac disease at an early stage then it will facilitate more aggressive and focused treatment of those at increased risk. The present study enlightens the association of elevated cardiovascular biomarkers with the documented cardiac pathological states (increased left ventricular mass index) in asymptomatic predialysis CKD patients. Previously it was thought that role of plasma NT-proBNP has been restricted to diagnose heart failure in patients with symptoms of dyspnea [18]. However, there is evidence that NT-proBNP level increases in response to isolated ischemia and myocardial injury even in the absence of heart failure [19]. Among all the cardiovascular biomarkers plasma NT-proBNP had strongest correlation (spearman's rho correlation coefficient; 0.769) with left ventricular mass index $(p=<0.0001)$ Figure 1 and it was consistent with the studies which were done by Susan Vickery et al., [20] and Christopher R et al., [21]. In our study NT-proBNP levels were elevated in most of the patients who had known coronary artery disease and it was consistent with previous work of Christopher R et al., [21]. NT-proBNP levels appear to be increased to a greater degree in patients with CKD with underlying coronary artery disease or LVH. Thus it supports the hypothesis that underlying cardiac pathological state is responsible for elevated NT-proBNP levels in this predialysis CKD population. Patients with lower (eGFR) had higher plasma 
NT-proBNP levels and it was consistent with studies which were done by Vickery Susan et al., [20] and study done by Akshay S. Desai et al., [22]. Plasma NT-proBNP levels were correlated positively and significantly with serum CTn-T levels among predialysis CKD patients (spearman's correlation coefficient $r=0.488 \& p=0.0001)$ and it was consistent with the study which was done by Satyan et al., [23]. Plasma NT-proBNP levels correlated positively and significantly with serum hs-CRP $(p=0.0001)$ and and it was consistent with study which was done in non-dialysis CKD population by Susan Vickery et al., [24].

Levels of cardiac troponin are frequently elevated in the absence of acute coronary syndrome among patients with varying degrees of kidney disease [25]. For predialysis CKD patients, however, data are limited and conflicting. In our study prevalence of increased serum CTn-T in predialysis CKD patients was $22.5 \%, 37.5 \%$ and $60 \%$ in CKD stage3, stage 4 and stage 5 respectively and it was consistent with study which was done by Nasir A. Abbas et al., and by Landry et al., CRIB study $[25,26]$. Serum cTn-T was correlated positively and significantly with the left ventricular mass index $(r=0.479$ \& $p$-Value $=0.0001$ ) Figure 2 . The prevalence of $\mathrm{LVH}$ was $>50 \%$ in all 3 CKD stages. Increased serum CTnT was associated with LVH in 51\% patients (37/72) Figure 3 and it was consistent with study which was done by Nassir A et al., [25]. Serum CTnT was more likely to be increased in patients with diabetes (33 of 48) than in those without diabetes and it was consistent with study which was done by Nasir A et al., [25]. Serum cTnT was more likely to be increased in patients with history of coronary artery disease (38 of 47) than in those without history of CAD.

There are multiple associations with CRP levels and CVD outcomes in patients with CKD. It is associated with increased mortality across the full spectrum of CKD [27]. It is generally agreed that a hs-CRP concentration $>3 \mathrm{mg} / \mathrm{L}$ is a strong risk factor for a coronary event [28]. Serum hs-CRP did not correlate with eGFR in our study and it was consistent with the study which was done by Christopher et al., [21]. Serum hs-CRP was correlated positively and significantly with left ventricular mass index $(r=0.246 \& p$-Value $=0.007)$. Serum hs-CRP correlated positively and significantly with spot urine albumin creatinine ratio $(r=0.192 \& p$-Value $=0.035)$.

In general, albumin to creatinine ratio has been shown to have slightly better diagnostic accuracy than urine albumin concentration alone for detection of albuminuria in many populations [29]. In addition to predicting CKD progression, proteinuria is a well-established risk marker for cardiovascular disease [30]. Spot urine albumin creatinine ratio was $>30 \mathrm{mg} / \mathrm{g}$ of creatinine in most of the predialysis CKD patients in our study and it was consistent with study done by Landry et al., Chronic Renal Impairment in Birmingham (CRIB) Study [26]. Spot urine albumin creatinine ratio was correlated positively and significantly with left ventricular mass index $(r=0.664$ \& $\mathrm{p}=0.0001$ ). Among cardiovascular biomarkers, plasma NTproBNP had strongest positive correlation (Spearman's rho correlation coefficient; $r=0.610)$ with spot UACR $(p=0.0001)$. Spot urine albumin creatinine ratio was correlated positively and significantly with serum $c T n-T(r=0.484 \& p-V a l u e=0.0001)$ and with plasma NT-proBNP $(r=0.610 \& p=0.0001)$ and it was consistent with the study which was done by Akshay $S$. Desai et al., [22]. Out of 120 predialysis CKD patients 41 patients (34.16\%), had spot urine albumin creatinine ratio $>1 \mathrm{~g} / \mathrm{g}$ of creatinine. Out of 41 patients who were having UACR $>1 \mathrm{~g} / \mathrm{g}$ of creatinine, 28 patients (68\%) had increased serum CTn-T and 40 patients $(97.6 \%)$ had increased plasma NT-proBNP. Spot urine albumin creatinine ratio was correlated negatively and significantly with the hemoglobin $(r=-0.507 \& p$-Value $=0.0001)$ and with eGFR ( $r=-0.641 \& p=0.0001)$ and it was consistent with the study which was done by Akshay S. Desai et al., [22].

\section{Conclusions}

Our present work showed that declining kidney function causes elevation of cardiovascular biomarkers early (CKD stage 3 in our study) and there is significant association of cardiac biomarkers with the left ventricular mass index. These biomarkers can predict cardiovascular risk in a predialysis CKD population with expected high cardiac morbidity and mortality.

\section{Competing interest}

The authors declare that they have no competing interests.

\section{Authors' contributions}

\begin{tabular}{|l|c|c|c|c|c|c|c|c|c|c|c|c|}
\hline $\begin{array}{l}\text { Authors' } \\
\text { contributions }\end{array}$ & SS1 & SS2 & HM & RJ & NS & HV & VK & AG & PK & SD & PR & HW \\
\hline $\begin{array}{l}\text { Research concept } \\
\text { and design }\end{array}$ & $\checkmark$ & $\checkmark$ & $\checkmark$ & -- & $\checkmark$ & -- & -- & -- & -- & -- & -- & $\checkmark$ \\
\hline $\begin{array}{l}\text { Collection and/or } \\
\text { assembly of data }\end{array}$ & $\checkmark$ & $\checkmark$ & $\checkmark$ & $\checkmark$ & $\checkmark$ & $\checkmark$ & $\checkmark$ & $\checkmark$ & $\checkmark$ & $\checkmark$ & $\checkmark$ & $\checkmark$ \\
\hline $\begin{array}{l}\text { Data analysis and } \\
\text { interpretation }\end{array}$ & $\checkmark$ & $\checkmark$ & $\checkmark$ & -- & $\checkmark$ & -- & -- & -- & -- & -- & -- & - \\
\hline Writing the article & $\checkmark$ & $\checkmark$ & $\checkmark$ & -- & -- & -- & -- & -- & -- & -- & -- & - \\
\hline $\begin{array}{l}\text { Critical revision of } \\
\text { the article }\end{array}$ & $\checkmark$ & $\checkmark$ & $\checkmark$ & $\checkmark$ & $\checkmark$ & $\checkmark$ & $\checkmark$ & $\checkmark$ & $\checkmark$ & $\checkmark$ & $\checkmark$ & $\checkmark$ \\
\hline $\begin{array}{l}\text { Final approval of } \\
\text { article }\end{array}$ & $\checkmark$ & $\checkmark$ & $\checkmark$ & $\checkmark$ & $\checkmark$ & $\checkmark$ & $\checkmark$ & $\checkmark$ & $\checkmark$ & $\checkmark$ & $\checkmark$ & $\checkmark$ \\
\hline Statistical analysis & $\checkmark$ & $\checkmark$ & $\checkmark$ & -- & -- & -- & -- & -- & -- & -- & -- & - \\
\hline
\end{tabular}

\section{Acknowledgement}

The authors express their gratitude to all the staff of nephrology and biochemistry departments of Ram Manohar Lohia Hospital for rendering their help. We express sincere thanks to statician D P Sharma for helping in data analysis and thanks to technicians in biochemistry department who helped in sample processing and quantification of biomarkers.

\section{Publication history}

EIC: Kevin R. Loughlin, Harvard Medical School, USA.

Received: 20-Apr-2014 Revised: 31-Jul-2014

Accepted: 11-Aug-2014 Published: 18-Aug-2014

\section{References}

1. Foley RN, Parfrey PS, Harnett JD, Kent GM, Martin CJ, Murray DC and Barre PE. Clinical and echocardiographic disease in patients starting 
Sathi et al. Clinical Nephrology and Urology Science 2014,

http://www.hoajonline.com/journals/pdf/2054-7161-1-4.pdf

doi: $10.7243 / 2054-7161-1-4$

end-stage renal disease therapy. Kidney Int. 1995; 47:186-92. | Article PubMed

2. Sarnak MJ, Coronado BE, Greene T, Wang SR, Kusek JW, Beck GJ and Levey AS. Cardiovascular disease risk factors in chronic renal insufficiency. Clin Nephrol. 2002; 57:327-35. | Article | PubMed

3. Roberts MA, Hare DL, Ratnaike $S$ and lerino FL. Cardiovascular biomarkers in CKD: pathophysiology and implications for clinical management of cardiac disease. Am J Kidney Dis. 2006; 48:341-60. | Article I PubMed

4. Baughman KL. B-type natriuretic peptide -- a window to the heart. $N$ Engl J Med. 2002; 347:158-9. | Article | PubMed

5. de Lemos JA, McGuire DK and Drazner MH. B-type natriuretic peptide in cardiovascular disease. Lancet. 2003; 362:316-22. | Article | PubMed

6. Wang $A Y$ and Lai KN. Use of cardiac biomarkers in end-stage renal disease. J Am Soc Nephrol. 2008; 19:1643-52. I Article I PubMed

7. Huseyin Bozbas, Aylin Yildirir and Haldun Muderrisoglu. Cardiac Enzymes, Renal Failure and Renal Transplantation. Clinical Medicine \& Research. 2006; 4:79-84. I Article

8. K/DOQI clinical practice guidelines for cardiovascular disease in dialysis patients. Am J Kidney Dis. 2005; 45:S1-153. | Article | PubMed

9. Panichi V, Migliori M, De Pietro S, Taccola D, Bianchi AM, Giovannini L, Norpoth M, Metelli MR, Cristofani R, Bertelli AA, Sbragia G, Tetta C, Palla $\mathrm{R}$ and Colombo $\mathrm{R}$. C-reactive protein and interleukin- 6 levels are related to renal function in predialytic chronic renal failure. Nephron. 2002; 91:594-600. | Article | PubMed

10. Pearson TA, Mensah GA, Alexander RW, Anderson JL, Cannon RO, 3rd, Criqui M, Fadl YY, Fortmann SP, Hong Y, Myers GL, Rifai N, Smith SC, Jr., Taubert K, Tracy RP and Vinicor F. Markers of inflammation and cardiovascular disease: application to clinical and public health practice: A statement for healthcare professionals from the Centers for Disease Control and Prevention and the American Heart Association. Circulation. 2003; 107:499-511. | Article | PubMed

11. Bakris GL. Microalbuminuria: what is it? Why is it important? What should be done about it? J Clin Hypertens (Greenwich). 2001; 3:99-102. I Article | PubMed

12. Levey AS, Coresh J, Balk E, Kausz AT, Levin A, Steffes MW, Hogg RJ, Perrone RD, Lau J and Eknoyan G. National Kidney Foundation practice guidelines for chronic kidney disease: evaluation, classification, and stratification. Ann Intern Med. 2003; 139:137-47. | Article I PubMed

13. Glassock RJ, Pecoits-Filho R and Barberato SH. Left ventricular mass in chronic kidney disease and ESRD. Clin J Am Soc Nephrol. 2009; 4 Suppl 1:S79-91. | Article | PubMed

14. Levey AS, Bosch JP, Lewis JB, Greene T, Rogers N and Roth D. A more accurate method to estimate glomerular filtration rate from serum creatinine: a new prediction equation. Modification of Diet in Renal Disease Study Group. Ann Intern Med. 1999; 130:461-70. | Article | PubMed

15. Devereux RB, Alonso DR, Lutas EM, Gottlieb GJ, Campo E, Sachs I and Reichek N. Echocardiographic assessment of left ventricular hypertrophy: comparison to necropsy findings. Am J Cardiol. 1986; 57:450-8. | Article | PubMed

16. Foley RN, Parfrey PS and Sarnak MJ. Clinical epidemiology of cardiovascular disease in chronic renal disease. Am J Kidney Dis. 1998; 32:S112-9. | Article | PubMed

17. Zoccali C, Benedetto FA, Mallamaci F, Tripepi G, Giacone G, Cataliotti A, Seminara G, Stancanelli B and Malatino LS. Prognostic impact of the indexation of left ventricular mass in patients undergoing dialysis. J Am Soc Nephrol. 2001; 12:2768-74. | Article I PubMed

18. Maisel AS, Krishnaswamy P, Nowak RM, McCord J, Hollander JE, Duc P, Omland T, Storrow AB, Abraham WT, Wu AH, Clopton P, Steg PG, Westheim A, Knudsen CW, Perez A, Kazanegra R, Herrmann HC and McCullough PA. Rapid measurement of B-type natriuretic peptide in the emergency diagnosis of heart failure. N Engl J Med. 2002; 347:161-7. | Article | PubMed

19. Weber M and Hamm C. Role of B-type natriuretic peptide (BNP) and NT-proBNP in clinical routine. Heart. 2006; 92:843-9. | Article | PubMed Abstract | PubMed Full Text
20. Vickery S, Price CP, John RI, Abbas NA, Webb MC, Kempson ME and Lamb EJ. B-type natriuretic peptide (BNP) and amino-terminal proBNP in patients with CKD: relationship to renal function and left ventricular hypertrophy. Am J Kidney Dis. 2005; 46:610-20. | Article | PubMed

21. DeFilippi CR, Fink JC, Nass CM, Chen $\mathrm{H}$ and Christenson R. N-terminal pro-B-type natriuretic peptide for predicting coronary disease and left ventricular hypertrophy in asymptomatic CKD not requiring dialysis. Am J Kidney Dis. 2005; 46:35-44. | Article I PubMed

22. Desai AS, Toto R, Jarolim P, Uno H, Eckardt KU, Kewalramani R, Levey AS, Lewis EF, McMurray JJ, Parving HH, Solomon SD and Pfeffer MA. Association between cardiac biomarkers and the development of ESRD in patients with type 2 diabetes mellitus, anemia, and CKD. Am J Kidney Dis. 2011; 58:717-28. | Article | PubMed

23. Satyan S, Light RP and Agarwal R. Relationships of N-terminal pro-Bnatriuretic peptide and cardiac troponin $T$ to left ventricular mass and function and mortality in asymptomatic hemodialysis patients. Am J Kidney Dis. 2007; 50:1009-19. | Article | PubMed Abstract | PubMed Full Text

24. Vickery S, Webb MC, Price CP, John RI, Abbas NA and Lamb EJ. Prognostic value of cardiac biomarkers for death in a non-dialysis chronic kidney disease population. Nephrol Dial Transplant. 2008; 23:3546-53. | Article I PubMed

25. Abbas NA, John RI, Webb MC, Kempson ME, Potter AN, Price CP, Vickery $\mathrm{S}$ and Lamb EJ. Cardiac troponins and renal function in nondialysis patients with chronic kidney disease. Clin Chem. 2005; 51:2059-66. | Article I PubMed

26. Landray MJ, Wheeler DC, Lip GY, Newman DJ, Blann AD, McGlynn FJ, Ball $\mathrm{S}$, Townend JN and Baigent C. Inflammation, endothelial dysfunction, and platelet activation in patients with chronic kidney disease: the chronic renal impairment in Birmingham (CRIB) study. Am J Kidney Dis. 2004; 43:244-53. | Article | PubMed

27. Menon V, Greene T, Wang X, Pereira AA, Marcovina SM, Beck GJ, Kusek JW, Collins AJ, Levey AS and Sarnak MJ. C-reactive protein and albumin as predictors of all-cause and cardiovascular mortality in chronic kidney disease. Kidney Int. 2005; 68:766-72. I Article I PubMed

28. Pearson TA, Mensah GA, Alexander RW, Anderson JL, Cannon RO, 3rd, Criqui M, Fadl YY, Fortmann SP, Hong Y, Myers GL, Rifai N, Smith SC, Jr., Taubert K, Tracy RP and Vinicor F. Markers of inflammation and cardiovascular disease: application to clinical and public health practice: A statement for healthcare professionals from the Centers for Disease Control and Prevention and the American Heart Association. Circulation. 2003; 107:499-511. | Article | PubMed

29. Bakker AJ. Detection of microalbuminuria. Receiver operating characteristic curve analysis favors albumin-to-creatinine ratio over albumin concentration. Diabetes Care. 1999; 22:307-13. | Article | PubMed

30. Trimarchi $H$, Muryan A, Dicugno $M$, Young $P$, Forrester $M$, Lombi F, Pomeranz V, Iriarte R, Rana MS and Alonso M. Proteinuria: an ignored marker of inflammation and cardiovascular disease in chronic hemodialysis. Int J Nephrol Renovasc Dis. 2012; 5:1-7. I Article I PubMed Abstract | PubMed Full Text

\section{Citation:}

Sathi S, Sunder S, Mahapatra H, J R, Sharma N, Verma H, K V, Gupta A, K P, Daksh S, Ram P and Wardhan $\mathrm{H}$. Role of novel cardiac biomarkers in prediction of cardiovascular risk in predialysis CKD patients by their correlations with left ventricular mass index. Clin Nephrol Urol Sci. 2014; 1:4.

http://dx.doi.org/10.7243/2054-7161-1-4 